\title{
A PROPÓSITO DE LA IMAGEN DE ANDALUCIA EN AMERICA DURANTE EL SIGLO XX
}

\author{
Inmaculada Cordero Olivero \\ Universidad de Sevilla
}

\begin{abstract}
RESUMEN
La imagen de un país en otro constituye un factor determinante tanto en la configuración de las identidades nacionales como en el establecimiento de las relaciones internacionales. Este artículo reflexiona sobre este tema y sobre la gestación y evolución de la imagen de España desde los siglos modernos hasta la reciente actualidad. Y pone el foco en el continente americano y en la imagen que allí se fue forjando de la antigua metrópolis a partir del proceso independentista de principios del siglo XIX. Esa imagen de España, pese a todos sus matices y pese a sus diferentes relecturas según los momentos históricos, tiene siempre un rasgo esencial: su identificación con Andalucía e incluso con una sola ciudad andaluza, Sevilla. La forma en que Andalucía se convirtió en la esencia de la identidad española y la difusión de esta imagen por los antiguos territorios hispanos y por los EE.UU. componen el resto del trabajo.
\end{abstract}

PALABRAS CLAVE: Imagen de España, Imagen de Andalucía, Leyenda Negra, Mito Romántico, Relaciones Internacionales, Viajeros, Emigrantes.

\section{ABSTRACT}

The image of a country in another is a relevant factor in shaping national identities in the establishment of international relations. This article reflects on this and on the gestation and evolution of the image of Spain from the modern centuries to the present. And it puts the focus on the American continent and the image that there was forged from 
the former colonial power from independence process. That image of Spain, despite all its nuances and despite their different reinterpretations, is always an essential feature: its identification with Andalusia and even a single city of Andalusia, Seville. The way that Andalusia became the essence of Spanish identity and the spread of this picture by the former Spanish territories and the United States make up the remainder of the study.

KEYWORDS: Image of Spain, Image of Andalusia, Black Legend, Romantic Myth, International Relations, Travelers, Immigrants.

Entre las muchas paradojas del periodo histórico en que nos encontramos llama poderosamente la atención la pervivencia de ciertos tópicos, clichés, estereotipos, imágenes de país, cuyo origen se remonta a la Europa del barroco y cuyo afianzamiento corrió paralelo a la construcción del Estado Nación a lo largo del S. XIX. La imagen de país continua siendo un argumento importante para entender la posición jerárquica que se le confiere en la sociedad internacional. El peso económico resulta vital, pero no dejan de ser importantes otros aspectos como el "prestigio" cultural o político. Por otra parte, la representación de un país en otro parece determinante para entender las relaciones bilaterales, de las que a su vez son producto. La "marca" de un país tiene importantes consecuencias en el terreno económico. Pero, sobre todo, esa imagen ha sido, ya en sus orígenes, un argumento central en la configuración de las identidades nacionales. La existencia del otro, del diferente, generalmente enemigo, facilita la homogeneización y la cohesión interna imprescindibles para la consolidación del estado nación contemporáneo. Esas imágenes históricas, congeladas y repetidas de generación en generación, afianzadas y divulgadas a través de la literatura, de los medios de comunicación y de los sistemas educativos nacionales, no parecen haber perdido fuerza en un periodo en el que se presume que las posibilidades de acceso al conocimiento del otro son infinitamente superiores a las de nuestros antepasados. Todo parece indicar que, incluso en la era de la tecnología, esas viejas representaciones del otro siguen constituyendo un factor de peso en las relaciones internacionales ${ }^{1}$. Eso explicaría por qué hemos asistido en los últimos años a la creación de numerosas entidades públicas y privadas encargadas de vigilar y crear imagen de España; de Andalucía en nuestro caso $^{2}$.

1 Sobre el tema de las representaciones del otro y su importancia en la relaciones internacionales recomendamos el texto de Genma Martínez de Esproceda, "Imaginación y Relaciones Internacionales", Hispania, n. 194, 1996, pp. 1097-1118, y "La Alemania de los ingleses", Historia Contemporánea, n. 16, 1997, pp. 143-183. Para el debate teórico se pueden consultar: Opinión publique et politique extrieure, I, 1870-1915, Ecole Francaise de Rome, 1981. Se trata de las actas de un coloquio en las que se incluyen reflexiones de sumo interés de Rene Girault, Daniel J. Grange y, sobre todo Piere Milza en su texto "Opinión publique et politique Etrangere", pp. 663-687. De igual manera, son interesantes las apreciaciones de J. Carlos Pereira en "La actitud británica ante el golpe de estado de Primo de Rivera: imágenes y percepciones, Hispania, n. 163, 1986, pp. 353-390.

2 La aprobación por parte de la Junta de Andalucía, en septiembre de 2009, del proyecto Andalucía 10 para vigilar y divulgar una imagen moderna de la autonomía, no es más que la última iniciativa de una corriente en la que se inscriben otras muchas tanto públicas, como privadas. La Fundación Elcano, por ejemplo, investiga y publica documentos de estudio y análisis sociológicos sobre la imagen de España en el extranjero; elabora, además, los denominados Eurobarómetro y Latinobarómetro, para medir regularmente esa imagen en Europa y América Latina respectivamente; y mantiene un observatorio permanente de la visión de España 
Entendemos que la vigencia de esos clichés históricos, repetidos y releídos hasta la saciedad, responde además a dos necesidades. En primer lugar, en el mercado global de mercancías y de cultura, el consumidor actual tiene tal cantidad de posibilidades de elección que necesita procesar la información, y para ordenarla apela a los estereotipos nacionales, categorías simples, generalizaciones históricamente enraizadas, que le permiten establecer codificaciones que le aseguran, por ejemplo, que una cámara fotográfica japonesa es de mayor calidad que una fabricada en Andalucía. Por otra parte, la globalización puede generar una reacción contraria y reforzar, por miedo, la defensa de unas señas de identidad diferenciadas. Al contemplar la imagen que tenemos en el exterior estamos reforzando la identidad propia frente al otro, creando autoimagen, cohesionándonos como grupo ${ }^{3}$. En esta coyuntura, el interés por las representaciones del otro se multiplica.

\section{Sobre la mirada del otro}

Cuando nos referimos a las representaciones de un país en otro aludimos a una realidad compleja, en la que se han de tener en cuenta múltiples factores. Ninguna mirada resulta inocente, se trata de un juego de espejos utilizado para criticar en los defectos ajenos los propios, para ensalzar cualidades propias o para ejemplificar lo que no se quiere ser. Además, esa visión del otro puede servir para distraer la atención de problemas internos, o para conseguir la alianza de intereses y la definición de identidad frente a un enemigo común. La identidad nacional aparece en parte por si misma, pero, sobre todo, frente a los demás; desde el otro. Por otra parte, desde la perspectiva del observado, del otro, esa mirada cumple también una importante función cognitiva, la de conocerse a si mismo a través de la imagen que proyecta, lo que se denomina "efecto espejo".

Esas representaciones de una colectividad en otra, cuajadas de estereotipos, llegan a los miembros de la misma en el proceso de socialización, a través, sobre todo, de los manuales escolares. Son las imágenes así aprehendidas las que engrosan la esencia

en la prensa extranjera. La Fundación Carolina tiene como línea de acción prioritaria la formación de jóvenes líderes de opinión para América Latina y España que, por supuesto, se encarguen de transmitir una imagen positiva del país. A esa labor ha contribuido también el Instituto Universitario Ortega y Gasset, facilitando el encuentro académico entre España y América. La creación de la marca España y el trabajo de los organismos dependiente del ICEX y de la AECI tienen el mismo objetivo prioritario. En el aspecto cultural es el Instituto Cervantes el encargado de difundir la cultura española por el mundo. Como en tantas cosas, y esto resulta también tópico, el Instituto sigue la senda marcada por los institutos franceses dispersos por el mundo. Ese esfuerzo tiene en Andalucía su reflejo en la magnífica labor del Centro de Estudios Andaluces, una de cuyas líneas de investigación más importantes es la de la imagen de esta autonomía en el exterior, y en el trabajo de la agencia EXTENDA, encargada de la promoción exterior de Andalucía en su vertiente más económica, con sedes en Buenos Aires, México, Miami, Nueva York, Panamá, Santiago de Chile y Sao Paulo.

3 El interés por el tema en España tiene una fecha clave, 1992. En torno a la celebración del V Centenario se plantearon toda una serie de iniciativas, política, culturales, académicas, destinadas a ofrecer una nueva imagen en el mundo, una vez superado con éxito el proceso de transición democrática. Un segundo repunte del interés por el tema se daría en lo años 90, de forma paralela a la internacionalización de la economía española y la exportación de capitales, fundamentalmente a América Latina donde ese proceso generó numerosas reticencias en la opinión pública. Los esfuerzos políticos han tenido, como era de esperar, su reflejo en el ámbito académico, pues en buena medida se investiga lo que se financia. 
de la representación de un país en otro, puesto que la probabilidad de modificarla a través del contacto directo es mínima para la mayoría de la población. Con todo, no conviene olvidar el protagonismo de la literatura de viajes y de los mass-media en la creación y difusión de esas representaciones. Finalmente, queda un factor cuyo papel en la creación de imagen de un país en otro conviene tener presente por ser el referente más directo, la actuación de las colectividades de inmigrantes. Nada como los comportamientos de esos inmigrantes en los países de acogida representa mejor para estos la forma de ser aquellos; sobre todo si, como suele ocurrir, esa comunidad asume el papel de agente de su país ante aquel que los observa.

Los medios de comunicación, la emigración, los libros de texto, los de viaje, son simultáneamente creadores y receptores de la imagen de un país en otro en un momento histórico determinado. Ahora bien, esa mirada está determinada también por las necesidades del observador y el estado de las relaciones entre éste y el observado en una coyuntura histórica concreta.

Mas que conocer la realidad, en su múltiple y complicada extensión, el individuo la percibe de forma selectiva y las asimila en forma de imágenes. Se trata de ordenar la realidad simplificándola. Además, no la recibe individualmente, sino como parte de una colectividad. Esa representación siempre es social. En el caso de la imagen de un país en otro esas percepciones están compuestas a base de clichés, estereotipos básicos, simples. En palabras de Emilio Lamo de Espinosa, la imagen de un país en otro sería:

un mapa cognitivo que simplifica una realidad poco conocida para hacerla manejable y comprensible; es pues un producto de la economía de pensamiento y su semejanza inmediata es con los mapas que, al igual que los estereotipos, destacan y resaltan aquello que resulta relevante. En uno y otro caso no se trata de reflejar la realidad sino de destacar lo que es socialmente importante para poder desenvolverse sin cometer demasiados errores ${ }^{4}$.

Podemos definir la imagen de un país como el conjunto de mapas cognitivos que sobre sus gentes y su historia se tiene en aquel que le observa. Integran esos mapas una serie de instantáneas congeladas, generalizaciones resultado de la ignorancia, no por ello totalmente falsas, relativas pero lógicas, que permiten a los individuos clasificar la información que recibe en un momento determinado a través de los mass-media ${ }^{5}$. Lamo de Espinosa apunta que una imagen nacional la configuran múltiples elementos, entre los que se encuentran, como mínimo, un conjunto de características que destacan, bien por su semejanza con el observador, bien por su diferencia con él. Esa semejanza o diferencia no dependen de la realidad del observado, sino "de su contraste con las expectativas del espectador, pues las imágenes, como estereotipos, se construyen a través de la comparación

\footnotetext{
4 Emilio Lamo de Espinosa, "La imagen de España en el exterior “, Leviatán, n. 66, 1996, p. 7.

5 Conceptualizada como la "opinión global” por Pierre Milza, como el "clima de opinión” por Otto Baunhauer y como la "opinión pública " por Lippman, de acuerdo con el cual "las imágenes que se hallan dentro de las cabezas de los seres humanos, las imágenes de si mismos, de los demás, de sus necesidades, propósitos y relaciones son sus opiniones públicas". Para este tema remitimos además a Baunhauer, "Clima de opinión, control social, un acercamiento sistemático general”, La opinión publica, México, 1976, pp. 5-27 y Walter Lippman, Public Opinion, New YorK: Harcourt Brace, 1922. Existe una traducción de esta obra publicada en Buenos Aires: Fabril, 1964.
} 
(frecuentemente tácita, oculta, inconsciente) entre lo que se ve y lo que se espera ver"'. No se trata de una fotografía, ni siquiera simplificada. Por otra parte, no son fruto de la racionalización, no se puede buscar en ellas ni coherencia, ni unidad. Las variaciones, las contradicciones y yuxtaposiciones no resultan extrañas. Además, puede haber tantas imágenes como ideologías, como grupos sociales existan en una colectividad. Esas imágenes nacionales contienen una fuerte carga de cainismo y exageran lo que entienden por "rasgos nacionales" generalizándolos, haciéndolos extensibles a todos sus habitantes. Lo mas problemático suele ser que esas representaciones nacionales llegan a tener más valor que la realidad misma; incluso para los que forman parte de ella. Esas imágenes tienden a autoalimentarse. En todo caso, éstas cumplen una función social al permitir al individuo sentirse seguro al entender y clasificar la realidad compleja que le rodea.

Los antropólogos y los psicólogos sociales que se han ocupado ampliamente del tema de las identidades nacionales destacan la importancia de la mirada del otro para la formación de la misma. Parece evidente que esa identidad propia se construye a partir de la del extraño, por contraposición a aquella; sobre todo si el otro es el vecino geográfico, el enemigo histórico, o aquel país con el que se ha mantenido una relación de dependencia, como es el caso de España en América ${ }^{7}$. Esa imagen

...marca la frontera del grupo étnico, estableciendo quienes son los otros frente a los que el grupo se define. En esa definición hay una intencionalidad subyacente de refuerzo identitario ...de forma que acaban por establecerse demarcaciones del otro frente a un nosotros ${ }^{8}$

En realidad, más que sobre imágenes, esas identidades se definen sobre estereotipos. El concepto de estereotipo se asemeja a la existencia de una imagen media, o suma de los elementos en común constantes que aparecen reflejados en varias imágenes. Vendría a ser la fosilización de una imagen determinada, construida en una etapa esencial, que permanece en el tiempo con muy escasas variaciones. Ante una realidad compleja y a veces confusa el estereotipo, más simple que complejo, más falso que verdadero, de segunda mano y resistente al cambio, pero, por lo general, coherente, permite al individuo entender lo que le rodea ${ }^{9}$. No obstante, mientras el estereotipo se

6 Emilio Lamo de Espinosa,’La imagen de España en el exterior”, op. cit., p. 7.

7 En el caso español, por ejemplo, la configuración de la identidad nacional tiene en Francia "el otro". Un grupo de investigación (CRODEC) dirigido por J. R. Aymes y conformado por numerosos hispanistas de la Sorbona, se ha ocupado de ese tema en los últimos años. En el estudio del juego de influencias y modelos entre los dos países y de la naturaleza de los contactos y conflictos, la imagen de Francia en España y viceversa tiene un papel protagonista, sobre todo en los orígenes de la edad contemporánea. De la función que tiene la imagen como espejo en el que mirarse para tomar conciencia de sí mismos, para definirse frente o contra el otro desde una perspectiva etnocéntrica que da a esas imágenes estereotipadas rasgos de prejuicio, dan cuenta los resultados del trabajo de este grupo, entre los que están la obra de Jan-Rene Aymes y Javier Fernández Sebastián, L 'imag de la france en Espagne 1808-1850, Preses de la Sorbone Nauvelle, Unv. País Vasco, 1997.

8 Alicia Gil Lázaro, “¿Hidalgo o gachupín? Imágenes en torno al inmigrante español en el México revolucionario”, en Sánchez Andrés, A. et al., Imágenes e imaginarios sobre España en México, México: Porrúa, 2007, p. 367.

9 Esta definición enlaza con la de estereotipo, ya clásica, emitida en los años 20 por Walter Lippman como imágenes de un pseudoentorno que pretenden representar a la totalidad cuando solo representan una parte de esa realidad y la representan falseada. 
vincula a los prejuicios y los tópicos, la imagen aparece como una simplificación de la realidad con la que mantienen un equilibrio que le permite ser verosímil ${ }^{10}$. Eso la posibilita para ir transformándose en el tiempo, frente a la permanencia de los estereotipos. En todo caso lo hace lentamente, como cualquier proceso mental. De igual manera, ese equilibrio le permite, incluso, presentar cierta pluralidad, por la existencia de varias imágenes paralelas ${ }^{11}$.

Lo que se llama carácter de un pueblo, sus rasgos, sus propensiones, el estilo de su comportamiento, su exteriorización vital en conjunto, no deja de ser en cierta medida una construcción intelectual montada sobre abstracciones: un esquema mental. De la inagotable variedad humana se han extraído, seleccionado y aislado ciertos elementos que en un momento dado se estimaron "típicos" por creer que expresan con mayor propiedad, vigor o constancia una profunda manera de ser, una supuesta esencia nacional que en atención a su presente y a su pasado se le atribuye a ciertas colectividades históricas. Pero, una vez constituida tal imagen, quizá convincente, como pueden serlo las instantáneas del turista, pronto se erige en paradigma y adquiere un valor perceptivo, no solo como pauta de interpretaciones venideras, sino también -lo que es más curioso- en cuanto modelo válido para los miembros de la propia colectividad, quienes con deliberación o sin ella procuran entonces ajustar a él sus actitudes y satisfacer así las expectativas vinculadas al correspondiente esquema ${ }^{12}$.

Esos "deslices freudianos", como los denomina Varela Ortega, terminan formando parte sustancial de unas imágenes nacionales tan antiguas como estables.

10 La diferencia entre el término tópico y el estereotipo no es otra que el grado. Para encontrar el significado
exacto del término podemos acudir a la antropología: "del griego TOPIKOS, se refiere a una generalización
abusiva de ciertas notas o caracteres habituales de un pueblo o región. Y de aquí se extraen unos principios
generales que se aplican a la ligera a todos los habitantes de un área determinada". De acuerdo con un método
tan antiguo como sencillo, cuyo fundamento es la economía de pensamiento, se tipifican como generalidad
lo que no pasan de ser rasgos particulares. Esas verdades a medias o simples mentiras, terminan convirtiéndo-
se en verdades incuestionables desde el momento en que son aceptadas por un grupo de personas como algo
real, caracterizan a los grupos humanos y van configurando ese mapa cognitivo que da forma a la imagen de
un país. No obstante, esos clichés no son tan simples como podrían parecernos. Caro Baroja señala que se for-
man con arreglo a criterios con pretensiones de sintéticos y bastante arbitrarios por lo general y siempre con
intenciones políticas. Emilio Temprano, España: la selva de los tópicos, Madrid: Mondadori, 1988, p. 22 .

11 Ya Aristóteles afirmaba que la naturaleza de las cosas se explicaba por su permanencia y creó la noción de estereotipo como carácter nacional que permanecía a lo largo de los siglos explicando los comportamientos de los individuos y grupos. Pero fue la escuela historicista alemana, romántica y nacionalista, preocupada en la búsqueda del genio de los pueblos, la que constituyó un hito en la literatura sobre los estereotipos y las imágenes nacionales. En la actualidad, es la literatura anglosajona la más preocupada por el tema. José Varela apunta que es la existencia de un electorado muy complicado, con múltiples grupos diversos, lo que hace resurgir el interés por el estudio de los estereotipos. Dos son las escuelas que se ocupan del tema, según apunta el profesor. De una parte la que denomina psicoanalista, basada en la idea freudiana de que la frustración genera reacción, entiende que el estereotipo cumple una función de desplazamiento de culpa o frustración contra el enemigo que se convierte en un chivo expiatorio. La otra entiende el estereotipo como una simple categoría simplificadora, un prejuicio utilizado de una manera muy simplista y un juicio rápido de un realidad

12 Francisco Ayala, La imagen de España, Madrid: Alianza, 1986, pp. 28-29. 
Varela asegura que la imagen de España conserva mucho de los elementos de las primeras impresiones transmitidas por autores grecoromanos sobre los territorios conquistados y sus habitantes. Desde ese momento, "lo que se han dado son progresivas relecturas de aquella estampa, repitiéndose conceptos que, reelaborados, llegan a un punto clave en la edad moderna y el reinado de los Reyes Católicos"13. En ese ambiente cultural es donde las definiciones sobre el carácter de los pueblos toman forma, y con ella se estereotipan cualidades y defectos que quedan fijados de manera permanente.

... a los ojos de muchos tratadistas de comienzos del siglo XVII Europa se presenta como un conjunto de Estados, caracterizados por su respectiva dimensión nacional. En consonancia con esa visión, a cada uno de ellos le corresponde unas determinadas cualidades, también fija y casi inmutables, que son atributos indiscutibles del conjunto de sus habitantes. Los había soberbios y crueles como los españoles, codiciosos como los franceses y poco fiables como los italianos. Algunos pecaban de simples y otros de ser proclives a todo tipo de excesos; fieros y taimados, nobles y envidiosos. Los adjetivos podían variar o repetirse en algunos casos según las épocas y los autores, pero la semblanza moral que identificaba a los unos a los ojos de los otros se mantiene casi siempre. Fuese esta positiva o negativa, no lo era debido a causas y circunstancias cambiantes, sino per se y desde siempre, en virtud de sus misma naturaleza ${ }^{14}$.

La posición en el sistema de poder de la Europa moderna iba a ser clave. Desde entonces, asistimos a continuas relecturas de los mismos tópicos. Eso sí, apreciados de distinta manera según la etapa de la historia de la cultura occidental por la que transitemos.

Por todo lo dicho, la imagen de un país en otro en una coyuntura histórica determinada es resultado de la interacción de dos planos diferentes. Se trata de la acción dialéctica entre el "plano emergente", la información que sobre lo que ocurre en el observado llega al observador en un momento concreto, y un plano que corresponde a la "identidad cultural", de la que forman parte la historia y, sobre todo, los estereotipos a los que nos hemos referido ${ }^{15}$. En ocasiones la información que llega confirma la imagen estereotipada que se tiene del objeto de la mirada. Otras veces ocurre lo contrario. Pero, muy raramente se transforma esa imagen de país, cuesta trabajo y tiempo. Generalmente, cuando la información que llega no se ajusta o contradice los viejos tópicos el observador continua esperando que estos reaparezcan, antes o después. Siempre resulta más seguro entender la realidad del otro según parámetros históricamente heredados, que modificar esas apreciaciones. Algo así ocurre con la imagen de España en el extranjero durante la Transición Política.

13 A. Sanguesa "La fuerza de la mirada", Pabellón de España, nº, agosto de 1991, p. 8.

14 M. Victoria López Cordón y J. M. Jover Zamora, "El descubrimiento barroco de la identidad nacional", Historia de España, t. XXVI, Madrid: Espasa, 1986, p. 391.

15 Pierre Milza, "Conclusión. Opinión publique et politique étrangére”, Opinión publique et politique extraterieure, Roma, 1981, pp. 11-41. 


\section{La imagen de España}

Francisco Ayala asegura que la imagen de España se erige sobre un principio fundamental, el de la extravagancia. La Europa burguesa y capitalista de las nacionalidades, en la que triunfa el modelo protestante, vió en aquella el baluarte del modelo superado, el del catolicismo de la contrarreforma y el antiguo régimen. Esa mirada, inflada de una curiosidad, a veces risible y otras atónita ante lo que se considera distinto, por inferior, aparecía deformada en dos direcciones: la de lo pintoresco y la de lo tenebroso.

...nuestra extravagancia, el "sin sentido" de nuestra realidad para los ajenos, se concreta en una deformación caricaturesca polarizada, según el sentimiento que domina el complejo emocional, en dos direcciones fundamentales: la que se complace en el tipismo y la que se horroriza con la leyenda negra ${ }^{16}$.

Esa imagen de España, bipolar y antagónica, la de la pandereta y la de la leyenda negra, producto de la incomprensión, cristalizó como definición de lo español; también, por extensión, de lo hispano. Desde entonces, pocos países han sufrido como éste las consecuencias de esos prejuicios históricos afincados con fuerza en la mentalidad colectiva occidental.

Ya en la edad moderna cuajó el tópico de la España amenazante. En los albores de la contemporaneidad la imagen de España estaba estructurada en torno a unos "cromos" históricos que dibujaban tres arquetipos humanos: el monje, el hidalgo y el conquistador.

...las torturas de la inquisición, la crueldad de la conquista de América, la figura del monje glotón y lascivo, la salvaje soldadesca en plena masacre de inocentes (Alba saqueando los Países Bajos por ejemplo), la indolencia de los aristócratas, el latifundio como sinónimo de feudalismo... ${ }^{17}$.

Esos clichés, que en la Edad Moderna todavía escondían un evidente respeto hacia una potencia hegemónica, se transformaron hasta convertirse en una caricatura. Lo temible pasó a ser ridículo y la imagen de España se fue asociando a la idea de decadencia y miseria, que los filósofos viajeros del XVIII se iban a encargar de divulgar con afán paternalista y regenerador. El Imperio católico transformado en la España decadente adquiría una función ejemplarizante. La decadencia española constituía una

\footnotetext{
16 Francisco. Ayala, La imagen de España, Madrid, Alianza, 1986, p. 22. Para la imagen de España remitimos a tres textos que consideramos de sumo interés para el tema, el libro de Rafael Núñez Florencio, Sol y sangre, La imagen de España en el mundo, Barcelona: Espasa, 2001, el monográfico de la revista Ayer, coordinado por Ismael Sanz, "La mirada del Otro", n. 31, 1998 y el dossier "España: La mirada desde fuera", de la Revista Historia del Presente, n. 11, 2008.

17 E. Ucelay Dacal, "La imagen internacional de España en el periodo entreguerras", Actas inéditas del Simposio Internacional la mirada del otro: la imagen de España en el extranjero, Sevilla, marzo de 1992, op. cit., p. 3.
} 
advertencia para aquellos filósofos viajeros franceses e ingleses del siglo de las luces, un ejemplo de lo que no se debía hacer ${ }^{18}$.

Esa denostada representación de España se articulaba en torno a varios hilos conductores: la monarquía católica; una Iglesia ultramontana, vinculada indisolublemente a la Inquisición; un pueblo contradictorio, con Quijotes y Sanchos, pasional, extremo, violento, capaz de alcanzar la magnificencia y caer en la ruina.

Estos estereotipos se congelaron, hasta convertirse en la tradición oficial de las culturas nacionales construidas en el XIX. Desde entonces, los rasgos de esa imagen de España han permanecido casi inalterables hasta la actualidad, si bien fueron objeto de continuas relecturas, en tono positivo o negativo, al hilo de la evolución de la cultura occidental. La visión crítica de la Ilustración, se tornó apologética durante el romanticismo. Más tarde, conforme se extendía el positivismo, la imagen volvería a ser crítica, y de nuevo romántica durante la Guerra Civil y en el curso de la posmodernidad.

Uno de los fenómenos más importante en la historia de la cultura contemporánea es el aumento del sujeto con acceso a la cultura, como causa y consecuencia del crecimiento de los índices de alfabetización, de la circulación y abaratamiento de los libros, y de la prensa. Esa socialización de la cultura coincide con el momento en que España, en realidad Andalucía, termina convertida en categoría de la cultura romántica para todo occidente. La guerra de la Independencia permitió que, la entonces hegemónica, Gran Bretaña se convirtiese en aliada de su antigua enemiga. Los soldados ingleses convivieron con el pueblo español, y lo que antes eran defectos pasaron a convertirse en virtudes: la crueldad se trasformó en heroísmo, el individualismo en arrojo, la soberbia en orgullo. De otra parte, los tesoros artísticos españoles inundaron los mercados europeos como consecuencia del expurgo francés, poniendo de moda la pintura costumbrista de la escuela andaluza. Lo mismo ocurrió con la literatura del Siglo de Oro. Lope de Vega o Quevedo fueron redescubiertos para la cultura occidental, a la par que Shakespeare. De acuerdo con los parámetros del romanticismo europeo España era un país romántico antes incluso de que la sensibilidad romántica hubiese surgido. Así lo confirmaban su historia, desde la Reconquista hasta la guerra de la Independencia, y la mentalidad de su pueblo, desde esa forma irracional y personal de entender la religión, al salvaje heroísmo, la valentía, la falta de racionalidad y de previsión que les llevó a creer que podían luchar contra la Gran Armee y conseguirlo.

Ante eso, los viajeros que el siglo XVIII habían visitado España con intención de redimirla, ahora la contemplan, salvo excepciones muy contadas, extasiados ${ }^{19}$. Esos viajeros, a quienes se les atribuye la invención de la imagen de Andalucía, no justificaron la invalidez de la visión ilustrada, más bien la confirmaron. Eso sí, dotándola de un sentido inverso. Recrean un país de contrastes, hijo de un paisaje que también lo

18 Esos viajes, en ocasiones falsos, ofrecían una imagen muy crítica en el caso francés y más benévola en el inglés. Unos y otros consideran la excesiva influencia de la Iglesia católica y al mal gobierno responsables del atraso de un país perezoso, indolente y apático, enemigo de las luces, ignorante de la filosofía, conservador y reaccionario. Con todo, a finales del siglo XVIII la crítica se suaviza y surge una imagen galante descrita por los viajeros prerrománticos, que augura la transformación radical del s.XIX.

19 Llama poderosamente la atención cómo las mujeres viajeras del siglo XIX y XX, que también las hubo, dibujan una España, una Andalucía más real, menos mítica y más social que el cuadro costumbrista que ofrecen la mayoría de sus contemporáneos varones. El texto de Alberto Egea, Viajeras románticas en Andalucía, Sevilla: Centro de Estudios Andaluces, 2008, es elocuente. 
era, donde se compaginan ingenuidad y corrupción, vida religiosa y civil, brutalidad y generosidad, pereza y laboriosidad, tristeza y alegría. En ella encuentran todo lo que buscan: el exotismo de lo diferente, frente a la unidad enciclopédica de una sociedad postnapoleónica angustiada; el primitivismo que se muestra en la simplicidad y en la fuerza, en la crueldad y el temperamento violento de los hispanos; el orientalismo de los bandoleros que les permite sentirse superiores; el individualismo, la dignidad, el concepto de honra y el orgullo, enraizados en el pueblo español; la pereza y la austeridad que responden a una concepción frugal de la vida, ese dejarse llevar por el azar sin un proyecto vital coherente tan del gusto romántico; la fascinante conjunción de fanatismo y de costumbres democráticas en un país aristocrático.

Sin duda, el mito de la España Romántica lo elabora un observador muy diferente al racionalista ilustrado, un ser desubicado en una sociedad que se uniformaba a la par que avanzaba el proceso de modernización. En ese contexto, el viaje resultaba un pretexto para llevar a cabo un recorrido introspectivo en busca del yo, a través de la conciencia del otro. La Península podía ser un islote en la Europa que se industrializaba y se homogeneizaba, con una sociedad opresiva y feudal, un Estado corrupto y un pueblo fanático, manejado por un clero ignorante. España seguía siendo un país inestable, violento y cruel, plagado de bandoleros, toreros, frailes y cármenes. Sin embargo, poseía un "toque diferencial" que la hacía apasionante, en cuanto primitiva y exótica, y que colmaba los gustos románticos. Ese recorrido iniciático era completamente subjetivo. Por eso inventaban bandoleros donde no los había, cerraban los ojos para no ver ciudades como Madrid o Barcelona, o exageraban hasta la saciedad, ya de vuelta a casa, aquello, real o inventado, que constituía "una aventura" 20.

Con todo, la embelesada visión romántica no dejaba de ser una mirada "desde arriba", sobre un país "diferente", por atrasado, que formaba parte de la periferia del sistema capitalista y que continuaba siendo "el otro" en un mundo en el que había triunfado el modelo anglosajón de desarrollo.

El darwinismo social de la etapa positivista recuperó la visión negativa de los ilustrados, reforzándola ahora con argumentos científicos que responsabilizaban al mestizaje cultural y étnico de ser la causa de la personalísima idiosincrasia española, en un momento histórico y cultural en que la consigna era la pureza y perfección de la raza.

En otro viraje del péndulo al que se asemeja la historia de la cultura occidental, el racionalismo positivista entró en crisis a finales del XIX, para ser sustituido por un neoromanticismo, patente en la intelectualidad europea antes del 98, pero que se generalizó tras la Gran Guerra. En ese contexto se recuperó la imagen romántica de España durante la Guerra Civil. En realidad, a lo largo de la contienda estuvieron vigentes en el imaginario colectivo occidental los dos visiones de España enfrentadas, la de la leyenda 
negra y la del mito romántico. Por motivos ideológicos se identificó la España negra con el bando contrario al que se pretendía defender y a la romántica aquél por el que se había optado. En realidad, se mantenía la vigencia del tópico de las dos españas.

Con todo, cualquiera que fuese la perspectiva ideológica del observador, había unos rasgos de la imagen de España que todos asumían. Esas características se consolidaron durante el Franquismo y demostraron su vigencia también durante la Transición: la imprevisión hispana y la capacidad de sorprender; en definitiva, la idea tan rentabilizada por el franquismo de España es diferente, sigue siendo "el otro".

\section{La imagen de España en América ${ }^{21}$}

La leyenda negra constituye un mito básico en el universo mental colectivo de los territorios que en un día formaron parte del imperio español. Teniendo en cuenta que en el mundo de los prejuicios lo importante no es la veracidad de los planteamientos, sino que expresen necesidades colectivas, actúen como fuerza motora o retardadora o como factor exculpatorio, se entiende que la visión negativa de España cumpliese una función clave durante la independencia y la formación de las nuevas nacionalidades. Si, como hemos apuntado, España constituyó “el otro" para parte de Europa y resultó un instrumento útil para criticar defectos propios y corregir errores, en el caso americano esos preceptos adquirieron especial significación.

En América Latina el acto fundacional de sus jóvenes repúblicas se llevó a cabo contra un enemigo común y contra una situación determinada: la dependencia colonial. Eso permitió que España fuese "el otro" en cada uno de ellos y que, además, su imagen permaneciese indisolublemente ligada a la etapa colonial. Como ha estudiado Will Fowler para el caso de México, el rasgo fundamental de la identidad de ese país es “su postura ambigua y paradójica ante lo español”. Desde la independencia, subsistían cuatro temas sobre los que sus habitantes habían de posicionarse constantemente: el legado indígena, el papel de la iglesia, el mestizaje y la necesidad de diferenciarse o de parecerse a España y a EEUU. Tomar partido frente a esos temas terminaba marcando las fronteras ideológicas entre la derecha hispanófila y una izquierda caracterizada por su hispanofobia ${ }^{22}$.

Sin embargo, la situación de México, aunque muy extendida por el continente, no es uniforme. Carlos Malamud apunta la existencia de matices cualitativos importantes en lo que se refiere al rechazo de la herencia hispana en América Latina. El grado de hispanofobia dependió de la forma en que se ejecutó la conquista y la independencia, pero también de las relaciones que cada país mantuvo con la antigua metrópolis después de la independencia ${ }^{23}$. Por lo tanto, ese antiespañolismo respondía a la evolución

\footnotetext{
21 Para este tema remitimos al libro coordinado por Rafael Sánchez Mantero, La imagen de España en América, 1898-1931, Sevilla: Escuela de Estudios Iberoamericanos, Para el caso específico de México se puede consultar nuestra monografía España en México, 1975- 82, Sevilla: Monte de Piedad-Colegio de Jalisco, 2005.

22 Will Fowler en "La hispanafóbica hispanofilia de Antonio López Santa Anna", Imágenes e imaginarios sobre España en México, op. cit., p. 4-7.

23 Carlos Malamud, "Una imagen reflejada en el espejo: la imagen de España en América desde la independencia hasta nuestros días", Revista de Occidente, no 131, abril de 1992, pp. 180-188.
} 
de cada República, a las necesidades de justificar errores, fallos o involuciones, surgidos en su nueva andadura independiente.

Aun cuando resulte precipitado explicar la imagen de España en América sin distinguir áreas, podemos aventurar, en líneas generales, una evolución parecida. Durante el siglo XIX la visión de España estuvo llena de resentimiento. Los referentes de las nuevas naciones fueron la cultura francesa, madre de las ideas liberales e ilustradas que inspiraron el movimiento libertador, y el mundo anglosajon, padres del progreso. La América hispana convirtió el capitalismo y la democracia de la República Federal Estadounidense en el modelo a seguir. A la par que eso ocurría "en las mentes americanas se planteó una sencilla ecuación: medieval, inquisitorial, conservador, igual a español católico; avanzado, moderno, progresista, igual a americano liberal"24.

Muy pronto, el positivismo y el darwinismo europeo dominarían los circuitos culturales y científicos de las nuevas repúblicas con su determinismo y su racismo. La implantación de sus principios provocó el rechazo de lo español, por decadente, y de lo latinoamericano, por ser hijo de la mezcla de una raza corrupta. El panorama que dibujaba el argentino Sarmiento con motivo de su viaje por tierras de Europa, África y América resultaba demoledor para España cuando asegura

...Si yo hubiera viajado en España en el siglo XVI, mis ojos no habría visto otra cosa que lo que ahora ven...opino porque se colonice España; y ya lo han propuesto compañía belgas...25

En ese clima intelectual, Sarmiento, Bilbao, Alberdi o Sierra, lanzaban la consigna de desespañolizar América, para, toda vez que se había demostrado los buenos resultados de la colonización puritana en EE.UU., "sajonizarla". Para conseguirlo se apuntaban como medidas a tomar: iniciar un "lavado de sangre", favoreciendo una masiva emigración anglosajona que hiciese por la América hispana lo que había hecho por la anglófona y llevar a cabo un "lavado de cerebro" que supusiese "la adopción del positivismo y el utilitarismo que permitiesen formar hombres prácticos que hiciesen de sus pueblos naciones semejantes a las Europeas, a los E.E.U.U." ${ }^{26}$. Sin embargo, la crisis del positivismo coincidió con un acontecimiento destinado a ser clave, la guerra hispano-norteamericana de 1898. El miedo a los EE.UU. favoreció la recuperación de elementos en común sobre los que fundamentar una alianza que permitiese a América Latina defenderse del "gigante del norte". Eso terminó permitiendo una nueva lectura del pasado y de las señas de identidad que los unían a todos y que eran españolas.

Por esos mismos años, otros factores permiten también explicar la mejora cualitativa de que es objeto la imagen de España. En primer lugar, en torno a 1870, los conflictos territoriales entre las nuevas naciones obligaron a mandar delegaciones a España, para investigar en sus archivos los límites territoriales exactos de las jóvenes repúblicas. Esta circunstancia, bastante usual en el cono sur, trasladó a la Península a numerosos

24 Beatriz Ruíz Gaitán, "La historia de España y la historia de EE.UU. en la integración de la historia Latinoamericana", Latinoamérica, no. 13, México, 1980, p. 411.

25 Domingo Faustino Sarmiento, Obras selectas, Viaje por Europa, Africa y América, Barcelona: Espasa, 2002 , p, 416.

26 Leopoldo Zea, "Hispano-América siglo XIX. Ruptura y reencuentro", Cuadernos Americanos, n 19, enero- febrero, 1990, p. 102. 
eruditos a los que el viaje permitió replantear ciertos tópicos, descubrir las innegables semejanzas entre su tierra y aquella, sentirse en ella " como en casa" ${ }^{27}$. Por otra parte, comenzaron a llegar al continente, al cono sur sobre todo, un importante contingente de inmigrantes. La presencia de italianos en el cono sur convirtió la raíz española en elemento de diferenciación frente a los recién llegados. Por otra parte, entre esos inmigrantes también iban muchos españoles. El contacto directo de los americanos con aquellos que iban a "hacer las américas", llevando una vida espartana de trabajo y ahorro, permitiría eliminar ciertos estereotipos. Aunque también es cierto, en países como México, que reafirmó otros al entender que pretendían de nuevo conquistar América, ahora con una estrategia distinta. No obstante, en general, la vida de estos emigrantes parecía ejemplar, hasta el punto que no pocos intelectuales de la época explicaban que América necesitaba una inyección periódica de hombres de España para progresar.

No cabe duda que los elogios al emigrante de alpargata que encontramos, por ejemplo, en el historiador mexicano Lucas Alamán, entraban en conflicto con afirmaciones que a mitad de siglo habían sido de uso corriente, como las de Ignacio Ramírez que apuntaba que "los españoles no han hecho en nuestros puertos sino una cosa buena: salir por ellos" 28 . Transcurrido un tiempo prudencial, los herederos de los antiguos criollos reivindicaban su herencia española estableciendo una frontera con las clases medias y bajas, cuya imagen de España continuaba por los mismo derroteros de la independencia.

Si bien 1898 actuó como bisagra en Iberoamérica entre una hispanofobia oficial y una hispanofilia oficial también, el auténtico reencuentro entre lo español y lo latinoamericano se produjo durante la República y la Guerra Civil. La defensa de lo español, entendido siempre en clave colonial, había sido hasta entonces patrimonio exclusivo de los conservadores americanos. La República implicó la reconciliación de la izquierda americana con esa España que intentaba liberarse de sí misma. La Península se convirtió en espejo para los americanos. En ella podían ver reflejados sus problemas, en ella podían criticar sus propios defectos. Mientras la izquierda se congratulaba por las reformas del primer bienio y las soluciones dadas a problemas que ellos también arrastraban, la derecha los utilizaba para disuadir a sus compatriotas. España era un campo de pruebas; como también lo fue durante la Guerra Civil. Cualquiera que fuese su ideología, los americanos iban a sentir como propia la guerra española. La derecha conservadora identificándose con el movimiento que pretendía recuperar la verdadera España, tradicional y católica. La izquierda hermanándose con la que entendían como última colonia en liberarse de si misma.

El triunfo de Franco supuso la confirmación de una visión de España acorde, en esencia, con la imagen estereotipada y conservadora con la que había roto la Repú-

27 Sin formar parte de ese primer contingente de viajeros americanos, pero muestra evidente de la importancia de esos viajes de "reencuentro" que los americanos comenzaron a realizar a la Península en el último tercio del siglo, Rafael Sánchez Mantero hace referencia al viaje de Ricardo Palma, quien asistió a los actos conmemorativos del cuarto centenario. Este viajero representa al americano que queda impresionado favorablemente por el régimen político de España, por sus gobernantes, por sus ciudades. Ese reencuentro le conduce a hacer un llamamiento al acercamiento entre españoles y americanos. "La imagen de España en el Perú", en La imagen de España en América, op. cit., pp. 118-119.

28 Ignacio Ramírez, "La desespañolización”, Obras de Ignacio Ramírez, tomo I, México: Editora Nacional, 1947, p. 315. 
blica. La derecha americana más reaccionaria no ocultó su admiración por un país que había encontrado la clave que le permitía conjugar progreso con orden, modernización con tradición. La izquierda entendió el triunfo de Franco y su permanencia como una desgraciada constatación de la imagen estereotipada de España, del carácter español y, por extensión, del latinoamericano. Contra esta visión pesimista, un importante contingente de exiliados españoles refugiados en tierras americanas se encargaría, a lo largo de esos años, de criticar y denunciar un régimen anacrónico, esforzándose, desde una importante presencia en la enseñanza y los medios de comunicación, por mantener la imagen alternativa surgida al hilo de la reconciliación de Hispanoamérica con la España verdadera, la republicana.

Finalmente, la imagen de España en aquellos países ha ido modificándose de forma paralela no sólo al cambio político, sino a una evolución económica que la ha convertido en un importante aliado comercial; especialmente desde su incorporación al proyecto europeo ${ }^{29}$. De esa manera, España se ha convertido de nuevo en un referente cotidiano en la vida de los Americanos, en los medios de comunicación y en la calle, despertando cierta "envidia" tanto en lo económico como en lo político.

El éxito de la imagen pública de la Transición fue utilizado conscientemente por España para transformar su imagen tradicional en la zona. La leyenda negra es sustituida por una nueva leyenda rosa configurada a lo largo de un proceso de transición política considerado como modélico para América Latina. Ciertamente, la imagen del país que rompe sus tópicos políticos históricos es netamente positiva; pero cada vez más lejana para América. Eso despierta una nostalgia difícil de ocultar que vemos reflejada en el mexicano Carlos Fuentes cuando denuncia el peligro de que España se deje hipnotizar por Europa y se olvide de su esencia americana,

...el peligro persiste de que España, al ingresar en la Disneilandia Comunitaria europea, se vuelva demasiado próspera, demasiado cómoda, demasiado consumista, sin suficiente autocrítica y olvidadiza de su otro rostro, su perfil hispanoamericano... ${ }^{30}$

Es el mismo sentimiento que expresa Ernesto Sábato cuando escribe:

Vengo a España temiendo no encontrar a quien busco, tan cambiada la he visto que temo no reconocerla. Temo que vayan a traicionar a Quijote, así dados como están a "gratificarse" con cosas compradas, y a toda

\footnotetext{
29 En la década de los setenta los bancos españoles llegaron a prestar a Argentina, México, Brasil, Venezuela y Cuba, cerca de 10 billones de dólares. Se había convertido en el país que, según el numero de habitantes, más compraba a Iberoamérica, siendo la balanza comercial cada vez más deficitaria para España a medida que importaba crudo de la zona. Entre 1975 y 80 invirtió en aquella zona un porcentaje superior al $75 \%$ del total invertido en el resto del mundo. Así lo apunta Silvia Enrich en Historia diplomática entre España y Iberoamérica en el contexto de las relaciones internacionales 1955-1985, I.C.I., 1989, p. 312. Sin duda ese proceso de internacionalización de la economía española que daba sus primeros pasos ha influido sobremanera en la imagen que los Latinoamericanos tienen hoy de España. Además, Además, lo que es más importante porque está más cerca de la vida cotidiana de los latinoamericanos, España había pasado de ser una tierra que expulsaba emigrantes de alpargatas a enviar una emigración altamente cualificada y a convertirse, finalmente, en tierra de emigración para muchos latinoamericanos por motivos tanto económicos como políticos.
}

30 Carlos Fuentes, El espejo enterrado, México: Taurus, 1998, p. 22. 
costa parecer ingleses o norteamericanos. ¡Por favor! ¿Que quedaría de los Iberos sin Quijote? ${ }^{31}$

Esa sensación no era nueva. El periodista Rubén Marín cuando visitó Andalucía en la fase del desarrollismo franquista ya profetizaba

...no puedo evitarlo, admiraré más la noble y pletórica escasez de España,

llena de cultura redomada y exquisita, que su próxima riqueza al tono de

la vulgaridad universal ${ }^{32}$.

En el caso de EEUU la imagen de España imperante hasta la Guerra Civil tenía mucho que ver con la guerra de 1898. La visiones de la España de la leyenda negra y de la España decadente, muy bien manipuladas por la prensa "amarilla" para legitimar la guerra, se habían congelado en lo que el hispanista Roger Kagan denomina "paradigma Prescott". De acuerdo con éste España representaba la antítesis de EEUU. "América fue el futuro- republicana, emprendedora, racional; mientras España -monárquica, indolente, fanática- representó el pasado"33. Philip Powell resumió en Arbol de Odio el discurso del que se nutría la hispanofobia norteamericana, calificando a los españoles como sanguinarios, crueles, traicioneros, fanáticos, intolerantes, y a la Iglesia inquisitorial como la institución que mejor los representaba. Con todo, esa visión comenzó a corregirse con la fundación en 1904 de la Hispanic Society of America. La fundación de esta sociedad marcó el inicio de un nuevo hispanismo en la élite norteamericana. Sin embargo, la población en general desconocía incluso dónde estaba situada la Península. La antigua hispanofobia dio paso, ya en la guerra civil, a lo que se ha dado en llamar el "paradigma Hemingway". Una nueva leyenda de España ahora identificada con un romanticismo violento, primitivo, teñido de sangre ${ }^{34}$. En definitiva, otra revisión del mito de la España romántica en cuya visión abundan los brigadistas internacionales que lucharon en la Península, Orwell, Dos Passos. Después de aquello, el franquismo no se encargaría de destruir el mito de la España romántica, sino que le encontró una rentabilidad inestimable. Pero tampoco la democracia lo haría. La imagen romántica de España sigue vigente en EEUU, con restos también de la leyenda negra. En realidad una visión neorromántica en la que el cine de Almodóvar tiene mucha responsabilidad, pero que tiene precedentes en la contracultura de los años 60, cuando muchos jóvenes norteamericanos en contra del modelo de vida americano deciden instalarse en Ibiza o en Andalucía, el nuevo parnaso romántico para los jóvenes hippies occidentales.

En el fondo, y esto es aplicable a la imagen en general de España en el mundo, el paradigma de Prescott y el paradigma de Hemingway no son imágenes opuestas,

31 Ernesto Sábato, España en los diarios de mi vejez, Barcelona: Seix Barral, p. 19

32 Rubén Marín, “La España que conocí”, Epoca, México, n. 4, agosto 1965, p, 63.

33 Kagan R., Spain in América: The origins of hispanism in the United States, , tomado de Stanley Paine, "Los Estados unidos y España: percepciones e intereses", Cuadernos de Historia Contemporánea, $2003, \mathrm{n}$. 25, p. 156.

34 El paradigma Heminway responde a una relectura del mito romántico difundido por el escritor norteamericano en obras como The Sun also rises o Por quien doblan las campanas. Su contrapartida, el paradigma Prescott, es a su vez una relectura de la leyenda negra difundida por el autor de History of Ferdinad and Isabella, 1837. 
sino complementarias. Son las dos caras de la misma moneda, pues ambas parten de un mismo supuesto que no es cuestionado:

España es diferente... Esa es la constatación básica, a partir de la cual unos sacan conclusiones negativas $\mathrm{y}$, otros, positivas pero no tanto por España misma ... ${ }^{35}$

\section{La andalucización de la imagen de España}

Ernesto Sábato, en el relato de sus últimos viajes a la Península, recuerda como uno de esos escasos momentos en los que "la vida parece llevarnos en andas", un rato pasado en Sevilla, una ciudad que "resiste" que conserva esa esencia de España que siente perdida en su viaje. Casi de la misma manera que el viajero romántico hiciera en el siglo XIX, ve en Andalucía y en concreto en Sevilla la esencia de la identidad española, lo que la hace diferente en un mundo cada vez más homogeneizado, norteamericanizado. El escritor casi mitifica su atraso, frente a la vorágine de un mundo consumido por el mercado global, encuentra en ella un remanso de paz, de regreso a la naturaleza, la nostalgia de un tiempo y un mundo perdidos. En resumen, una nueva relectura del mito romántico. Pero el texto, además, plantea la cuestión central de este trabajo: la andalucización de la imagen de España e incluso la sevillanización de la imagen de Andalucía.

Mucho antes que Don Ernesto viajeros como Lord Byron, en su visita a Andalucía en 1809, Benjamín Disraeli en 1830 o Charles Rochefort Scott, inventaron la Andalucía Romántica, cuyo estereotipo se extendió por Occidente gracias a la prensa y a los libros de viaje. A ellos se debe la fusión de la imagen de España con la de Andalucía, hasta existir una auténtica asimilación por parte de la primera de los caracteres de la segunda como seña de identidad de lo español como unitario; no olvidemos la función de espejo que tiene la imagen que se proyecta para reconocerse, tomar conciencia de uno mismo.

...el andalucismo queda como rasgo marcado en la caracterización del estereotipo español. La Carmen de Merimee y el subrayado efectuado por Meilac y Halevy para Bizet demuestran la anteposición de lo andaluz en detrimento de lo español cuando no su definitiva absorción.. ${ }^{36}$.

Ese peregrinaje en busca del paraíso perdido resulta, en realidad, un viaje a Andalucía, porque es la más diferente, la más exótica, la más pintoresca de las regiones de España. La práctica totalidad de los rasgos del mito de la España Romántica son andaluces.

...Para muchas generaciones Andalucía ha sido la cumbre del viaje por España, la encarnación -por así decirlo- de la España mítica, etapa final de una iniciación al Otro y línea fronteriza, tal vez también, entre occidente y oriente, y ya se sabe que éste representa la imagen mítica del Otro en el subconsciente colectivo del mundo occidental... ${ }^{37}$

\footnotetext{
35 Noya, J., Rodríguez, B., Ruiz Jiménez, A., La imagen de España en EEUU, Instituto Elcano, Documento de trabajo, n. 44/2008, p. 17.

36 Friedrich Wolfzettel, "Relato de viaje y estructura mítica”, en Romero Tovar, L., Libros de Viaje, realidad vivida y género literario, Akal, 2005, p. 10

37 Ib., p. 10.
} 
Se trata de una usurpación de los rasgos identitarios de Andalucía. Una absorción criticada tanto por los nacionalistas andaluces, como por quienes desde otros territorios del Estado Español no se sienten identificados con esa identificación de lo andaluz como español. Con todo:

La identidad de Andalucía tiene tal potencia que, en los medios de comunicación del extranjero, ha llegado a confundirse con la identidad de toda España. Andalucía no existe. Andalucía ha cedido históricamente, y no siempre voluntariamente, su poderosa imagen folklórica al resto del país hasta el punto de perder su identidad.... ${ }^{38}$

La más poderosa imagen de España en el extranjero sigue siendo esa que identifica lo andaluz como español. Eso continúa siendo así porque ha sido aceptado y conservado por el mercado cultural español como un universo de imágenes con las que resulta agradable y a la vez rentable autoidentificarse. El franquismo lo entendió bien y se propuso rentabilizarlo hasta límites caricaturescos. No sólo se reforzó esa andalucización de la imagen de España, sino que el cine folklórico del franquismo favoreció una sevillanización de la imagen de Andalucía

... Carmen es la culminación de Sevilla como invención. En ella confluyen la gracia, la libertad, el valor, la picardía, la marginación, el misterio, la fatalidad y el castigo, en un clima donde el olor es luz y aroma los colores. Es la apoteosis del sur, la última palabra de un largo discurso donde todo se ha dicho ${ }^{39}$.

En todo caso, antes de que eso ocurriese, en América Latina se entendía ya Andalucía como la esencia de su España. Por eso los debates que durante la Transición Política se suscitaron a cerca de la autonomía andaluza llamaron poderosamente la atención. La prensa latinoamericana, que bien podía entender las ansias particularistas de catalanes o vascos, fue mucho más reticente con la de los andaluces. Andalucía era el reencuentro con la esencia de lo español unitario. Ciertamente, publicaba un periodista mexicano, las decoraciones rupestres más antiguas abundaban al norte, pero no afectaban a España como unidad de cultura. La cerámica roja brillante del Neolítico, la cultura del Algar y de los Millares, la del vaso campaniforme, partieron de Andalucía e irradiaron por la Península. Además, Tarsessos era "la primera prueba documental de la existencia de España”. Cuando pirenaicos y cántabros continuaban cazando osos prehistóricos, Andalucía era ya romana. Más tarde, los ocho siglos de Islam no fueron extraños a la historia de España, sino configuradores de su especial esencia, aquello que la distinguía de otros pueblos de Europa. Finalmente, desde Andalucía España se lanzó a América. Todos los episodios clave en la génesis de la esencia de España habían tenido a Andalucía como protagonista. No sólo eso sino que lo fenicio, lo griego, lo cartaginés, lo romano, lo visigótico y lo árabe, lo cristiano y lo judío, disueltos en las esencias

38 Intervención del periodista José A. Martínez Soler en II Jornadas Dos siglos de imagen de Andalucía, coordinadas por el investigador del centro de estudios andaluces A. Egea, noviembre 2007.

39 Acto solemne de investidura como Doctor Honoris Causa del Excmo. Sr. Dr. D. Francisco Ayala y GarciaDuarte (Universidad de Sevilla 25-II-1994). Recogido por Rafael Utrera en Imágenes cinematográficas de Sevilla, edición digital, Alicante: Biblioteca Miguel de Cervantes, 2001, p. 4. 
andaluzas, formaron el caudal íntimo del ser español. .La Andalucía abierta y universal fue configurando el genio de España: "por genealogía, por riqueza de dones, el ser vivo andaluz forma un todo entrañable con el cuerpo y el alma del ser vivo español. Son un mismo ser de forma indisoluble". Por eso Andalucía era el alma de España ${ }^{40}$.

Por eso es también era el alma de América. La región más vinculada a aquella por herencia, por carácter, formaba, con el norte de Africa, el sur de los EEUU, México y todo el centro y sur de América, a excepción de Brasil, un pueblo señorial, romántico, sensible, valeroso. Una sola comunidad que tenía como símbolos la guitarra, el caballo y el sombrero, y como lazo de unión indisoluble idéntica postura ante la vida y la muerte" 41 .

\section{Creación y difusión de imagen de Andalucía}

El enorme éxito en América Latina del cine folklórico español tiene una gran responsabilidad, si no en la creación de esos estereotipos, sí en su congelación y exageración hasta convertirlos en tópicos que terminan identificando a todos los españoles de todos los tiempos. Ese cine tuvo sus orígenes en la II República pero vivió su etapa de máximo esplendor en la década de los 50 del siglo pasado; sobre todo en países como México que no mantenían relaciones diplomáticas con Franco y, sin embargo, había visto nacer una poderosa industria cinematográfica hispanomexicana. Jalisco canta en Sevilla es el prototipo de un cine que hizo mucho más por la imagen de Andalucía que todas las campañas institucionales financiadas por la Junta en los últimos años ${ }^{42}$. El cine ha difundido una imagen simple, costumbrista, hiperbólica, folklórica que se identifica con Sevilla.

Interesa mucho menos esa otra imagen que va abriéndose paso en las primeras décadas del siglo XX, la de la Andalucía trágica de los noventaiochistas; otra visión mítica en cuya construcción tuvo mucha responsabilidad Ortega y Gasset ${ }^{43}$. Esta es la Andalucía denunciada por viajeros norteamericanos como Dos Passos en Rocinante to The Road Again (1922), la del chileno Rafael Sanhueza Lizardi en Viaje por España (1899) o la del argentino Manuel Ugarte en Visiones de España (1904) ${ }^{44}$. La misma que vio el mexicano Rafael Arriola cuando vino a España, después de la muerte de Franco,

40 Rafael Arriola, “Andalucía Honda”, El Dictamen de Veracruz, 22-5-1980, p. 3.

41 Fernando Mantilla, “Guitarralandia”, Epoca, México, n. 2, junio 1965, p. 16-17.

42 Labanyi, Jo, "Lo andaluz en el cine del franquismo: los estereotipos como estrategia para manejar la contradicción", Centra, Documentos de la Fundación del Centro de Estudios Andaluces, Junta de AndalucíaH2004/02. Rafael Utrera, Imágenes cinematográficas de Sevilla, biblioteca virtual Miguel de Cervantes, p. 4 43 Demostrando la responsabilidad que la autoimagen tiene en la formulación de la visión de Andalucía en el extranjero, Ortega, en su Teoría de Andalucía, la identificaba con un ideal de vida vegetativo, paradisíaco, otorgando carácter intelectual, filosófico, fijando de esa manera como verdad indiscutible aquello que eran simples apreciaciones precipitadas e interesadas, el mito de una tierra pobre pero feliz.

44 Para el tema de los viajeros americanos en Andalucía la bibliografía es especialmente abundante. Para una recopilación de la misma ver Romero Tobar, L., Elguren, P., Los libros de viaje. Realidad vivida y género literario, Akal, 2005; Nuñez, Estuardo, España vista por los viajeros Hispanoamericanos, Madrid: ICI, 1985; García- Montón, I., García Romeral, C. "Viajeros americanos en Andalucía durante los siglos XIX y XX", Revista de Historia de América, n. 26, Universidad Complutense, 2000, 261-279; Lacomba, J. A, "La mirada ajena, Andalucía vista por los otros", Estudios Regionales, n.34, 1992, pp. 163-177. 
y comprobó que la Andalucía verdadera no era la colorista y folklórica que se ofrecía al turista, pues debajo del color y de la superficie latía una sensibilidad profunda. La Andalucía del cante jondo y no de la sevillana. Una región rica en pasado, que esperaba pacientemente el final del precario existir que la mala administración de sus dones había provocado. La visión espléndida de la España meridional encontraba así su claroscuro en la descripción de campos inmensos labrados por hombres y mujeres pobres, con una renta inferior a la media nacional, muy por debajo de Cataluña o Vascongadas. Una región estancada, mal aprovechada, con un ingrediente trágico que, sin embargo, presumía de ser un pueblo grande en la miseria ${ }^{45}$.

Tan ignorada como la Andalucía trágica solía ser la moderna, de la que daban cuenta las postales que en las primeras décadas del siglo comenzaron a difundirse entre un público cada vez más amplio. Entre ellas no sólo se encontraban imágenes de la Giralda, también del puerto de Sevilla o de las minas de Riotinto. A pesar de todo, las visiones de la Andalucía trágica y de la Andalucía moderna palidecían ante el abrumador peso del mito de la Andalucía Romántica, difundido con enorme éxito por el franquismo y asimilado, al menos en parte, por los propios andaluces.

Al margen de su rentabilidad turística, lo cierto es que en el imaginario colectivo latinoamericano mantenían su vigencia dos visiones de España, la de la conquista y colonia, y el mito romántico. Las dos se entienden íntimamente vinculadas a Andalucía.

Ya comentamos el poder que tienen los libros de texto para crear imagen de un país en otro. En los de América Latina suelen aparecer varios arquetipos de españoles: misioneros, emigrantes, conquistadores y encomenderos. Lo más interesante es que se identifica esos tipos con una región determinada. A los andaluces se les asociaba con la tropa de conquistadores y primeros colonos que llegaron a tierras americanas en el siglo XVI, gente pobre, que marchó de España cuando empezó a extenderse la ganadería y que, por el simple hecho de ser español, ascendió social y económicamente, en la mayoría de las ocasiones a costa de la explotación de los nativos. Existían importantes diferencias de matiz, según el país y el tipo de escuela al que iban dirigidos los textos, generalmente los mexicanos solían ser los más críticos y las escuelas públicas no confesionales las más duras. Con todo, a pesar del peligro de ser excesivamente esquemáticos, apuntaremos que los protagonistas de la conquista aparecían en los textos como una masa homogénea a la que se atribuían defectos y virtudes, más lo primero que lo segundo. De acuerdo con eso eran jóvenes, solteros, arrojados porque no tenían nada que perder, individualistas, codiciosos, crueles y amorales. Todos los textos parecen confirmar el origen meridional de esos hombres. Tanto es así que algún autor llegaba a la conclusión de que el peso de los andaluces "reviste trascendencia, pues explica el gran influjo que han tenido en México la psicología y la cultura del sur de España"46. Una vieja sentencia mexicana aseguraba que esos hombres eran representantes de "lo peor de cada casa". El conquistador era un hombre ungido por el espíritu medieval; un hijo de la Reconquista. En ella adquirieron las "cualidades" por las que eran denostados: la crueldad y el fanatismo extremos, aprendidos en los años de lucha y resultado de otra de sus grandes "fallas", su insaciable codicia. Al calor de la Reconquista nació

45 Rafael Arriola, “Andalucía Honda”, El Dictamen de Veracruz, 22-5-1980, p. 3.

46 José Miranda, H. de México, México: UNAM, 1983, p. 208. 
también el amor por lo sangriento, por el pillaje y el saqueo, lo que, según Alfonso Toro, aprendieron de los islámicos. Para finalizar, "la lucha contra los moros" fue también el origen de su profundo individualismo. Todos se consideraban caudillos, por lo cual no mantenían ningún sentido de la lealtad hacia sus jefes. Eso provocaba numerosos desórdenes, engaños y faltas de coordinación que, en ocasiones extremas como la noche triste, precipitaron auténticas catástrofes.

Con el cine y los libros de texto otro poderoso instrumento para la difusión de la imagen de los andaluces ha sido el contacto directo con ellos, a través de la emigración. Su importancia deriva de la identificación que los habitantes del país de acogida hacen entre los caracteres y comportamientos de los andaluces que con ellos viven y los rasgos genéricos de la forma de vida, la mentalidad y la cultura andaluzas. La práctica totalidad de los países del continente americano tienen algún centro andaluz, destacando sobremanera la existencia de 21 asociaciones en Argentina, dos en Cuba e igual número en México $^{47}$. Estas instituciones cumplen un valiosísimo papel de cohesión de grupo, fomentando los rasgos de identidad andaluza, manteniendo los lazos de unión con la comunidad de origen y difundiendo una imagen corporativa que, en la mayoría de los casos, refuerza la visión Romántica y folklórica de la misma. Eso nos remite a un asunto delicado, la asimilación de los tópicos, la creación de una autoimagen a través del espejo, de cómo nos ven los otros.

Finalmente, hay comunidades que no poseen una imagen de marca y pasan desaparecidas, pero ese no es nuestro caso. A lo largo de toda la contemporaneidad, y mucho antes, Andalucía fue visitada por cientos de viajeros. Muchos de ellos eran latinoamericanos que seguían la senda marcada por sus colegas norteamericanos -Ford, Irving, Brown, etc.- en busca de la imagen Romántica de España. No obstante, en su caso el viaje revestía un matiz diferente. En mayor o menor medida, pretendían recuperar su pasado, de ahí su preocupación por la esencia de España, que no dejaba de ser, en parte, la suya propia. En la segunda mitad del siglo XX, cuando hace su aparición el fenómeno del turismo de masas, esos libros de viaje han ido cediendo protagonismo a las guías de viaje. La característica más destacable de las mismas es el esquematismo, la brevedad; se trata de ver lo máximo posible en el mínimo tiempo, de vender lo que el viajero viene buscando. No puede haber en ellas, lógicamente, un análisis actual, realista y pormenorizado de Andalucía, sino una relectura, más tópica por más breve, de todos los mitos de la imagen romántica.

\section{¿Qué Andalucía?}

El dominio de la imagen romántica y su deriva folklórica del franquismo resulta avasallador. Los andaluces, como los mexicanos, apuntaba un periodista, nacen "envueltos por una luz, unos colores, unos aromas sabiamente cálidos, que se condensan plásticamente en su espíritu, abierto a la fantasía, a la aventura, a la vivacidad, a

\footnotetext{
47 Se trata de una investigación todavía en curso. El objetivo es conocer la historia de esas comunidades, su integración en el país de acogida y los lazos que mantienen con su comunidad de origen. Como protagonistas de la creación y difusión de imagen de Andalucía en el extranjero se les cursó una encuesta cuyos resultados, todavía muy provisionales, apuntan que la visión que transmiten es la de la Andalucía pintoresca, romántica y folklórica.
} 
la alegría, a la pena con aguardiente, a la pasión mística, al gozo de los sentidos, a la creación estética"48.

La más potente imagen de Andalucía se articula en torno a tres ciudades: Sevilla, a la que se acude para buscar los orígenes familiares o colectivos en el Archivo de Indias, Córdoba y Granada; y, en el caso de los viajeros Latinoamericanos, también Cádiz, por su vinculación con la independencia.

Comentamos con anterioridad la sevillanización de la imagen de Andalucía y es que esa ciudad solía atesorar todo lo que los viajeros latinoamericanos buscaban en España. La Puebla española, como la consideraban los mexicanos, la Lima española para los peruanos, solía ser la escala central en el viaje por tierras andaluzas. Sevilla era una ciudad sugerente y misteriosa, que invitaba a soñar y a buscar lo criollo debajo de lo gótico, morisco o renacentista. El turista europeo o norteamericano no podía captar su esencia como presumía de hacerlo el latinoamericano. Esa sustancia que el viajero Ricardo Rojas encontraba en la fe patética de la ciudad y en el habla. No era una ciudad romana, como lo era la esencia cordobesa según el visitante argentino, no era tampoco una ciudad mahometana como lo era Granada, había refundido todas las tradiciones andaluzas y las había recreado, por eso no era de extrañar que se la viese como la esencia de Andalucía.

...Toda Andalucía goza de un sol espléndido, pero en Sevilla, parece más luminoso; toda Andalucía respira un aire sutil, pero en Sevilla parece más ligero: toda Andalucía posee tierras de sabroso fruto, pero en Sevilla la tierra parece más generosa, la vida más jocunda ${ }^{49}$.

Así, con motivo de la Exposición Iberoamericana de 1929 un diario venezolano publicaba

.....cualquier esfuerzo, por grande que fuese, se hallaría ampliamente recompensado con una visita a Sevilla. Todo invita a permanecer allí por tiempo indefinido: la franca y generosa hospitalidad que se dispensa al forastero; la radiante hermosura de sus paseos y monumentos; la belleza de sus parque y jardines; sus frondosas alamedas; sus lindos balcones, floridos todo el año y el permanente bullicio de sus calles que contagian al visitante la alegría de la población y el optimismo de sus habitantes...! Quien pudiera vivir y morir en Sevilla! ${ }^{50}$

Todo estaba dicho, si había una Andalucía amarga, esa podía estar en una Córdoba repleta de ruinas, pero no en Sevilla. Todavía muy avanzado el siglo XX, el toreo, la Semana Santa y la Feria, seguían constituyendo la esencia de una ciudad con personalidad, que aceptaba el progreso, pero que apreciaba, por encima de todo, sus tradiciones. Hasta tal punto que parecía que "el honor del mediodía de España depende de la forma en que se llevan a cabo sus festejos sacros y profanos cada primavera" ${ }^{51}$.

48 Rafael Arriola, “Andalucía honda”, El Dictamen de Veracruz, 22-5-1980, p. 3.

49 Ricardo Rojas, Retablo Español, Losada: Buenos Aires, p. 129

50 "Recuerdos y paisajes de Sevilla", Nuevo Diario, Venezuela, 2-4-1917.

51 Virginia González Claverán, "Semana Santa: Sevilla devota y festiva”, Diálogos, n 125, 5 mayo 1985 , p. 41. 
Valente Arellano, en su columna diaria en El Siglo de Torreón describía la ciudad andaluza como la tierra prometida para todo aficionado taurino:

¡Imagínate compadre! ganaderías de toros bravos, el culto al caballo que en estas tierras es como en ninguna parte casi parte de la vida misma y luego, viñedos, vinos. Y esa afición andaluza tan enterada, tan conocedora del toro, verdadera afición a los toros no a los toreros. ¿Con que quieres comparar una tarde en Sevilla? Después de "refrescar manzanilla, irnos a la Maestranza, la del albero amarillo ya con un "pescaíto" frito en el estómago. Ver la corrida con la afición y el respeto con que en "Serva la Bari" se ve a un hombre vestido de luces jugarse la vida. Y luego la calle Sierpes a comentar la corrida tomando un cafelito con la Giralda ahí a unos pasos.... ${ }^{52}$.

Desde una perspectiva antropológica, la investigadora Virginia González describía las fiestas de la ciudad para la revista del Colegio de México comenzando por la Semana Santa, acto social, tan religioso como pagano, al que reconocía un inmenso poder de atracción:

Son varios los factores que contribuyen a emocionar al espectador de la fiesta, y todos a la vez impresionan los sentidos: el olor ceroso esparcido por los nazarenos que van fundiendo sus enormes cirios; el inconfundible olor a incienso que se percibe muy próximo a los pasos, y qué decir del gratísimo perfume de los azahares que invade la atmósfera sevillana. Tampoco hay que olvidar la música de los campanilleros, las saetas y el sonido de los tambores y trompetas, a cuyo ritmo acaba ajustándose el latir de los corazones. El esplendor visual de los pasos aunado a los factores antes mencionados, hace vibrar intensamente a quien tiene la suerte de admirar la Semana Santa de Sevilla ${ }^{53}$.

A la Semana Santa seguía la Feria de abril, un correr de ríos de vino de Jerez, palmas, cante, baile y toros. El Rocío y el Corpus completaban el ciclo vital de un pueblo que parecía no resistir el reclamo de su espíritu jovial y festivo.

La descripción que Raúl Andrade realizaba de esas fiestas en las últimas décadas del siglo XX llama poderosamente la atención, porque bien podía haber sido escrita un siglo antes. El periodista veía la Semana Santa de Sevilla como "un espectáculo, escalofriante y dramático, con una grandeza indefinible en su bárbara mescolanza fanática y pagana". Formaban parte de ese cuadro romántico, pintoresco y contradictorio, imágenes como estas: colas de nazarenos formando "hileras de fantasmas bajo una máscara funeral, que elevaban a la noche sus lamentos ennegrecidos"; el vino que corría para refrescar a los penitentes; vírgenes que portaban "trajes de lo que fueron cupletistas arrepentidas" o toreros jubilados; piropos frívolos a las imágenes que salen de la bocas de los gitanos; hombres que "desenfundan las facas y se matan gallardamente, en defensa de la Virgen de su preferencia particular" ${ }^{54}$.

52 Valente Arellano Flores, "Memorias del campo bravo", El Siglo de Torreón, 15-4-1979, p. 5.

53 Virginia González, op. cit., p. 43.

54 Raul Andrade, "La Semana Santa Andaluza”, El Porvenir, 7-11-1982, p. 6. 
El argentino Ricardo Rojas presumía que en todos los pueblos andaluces existía una íntima fusión entre lo occidental y lo oriental, pero mientras Sevilla refundía ambas tradiciones y en Córdoba lo cristiano se incrustaba violentamente dentro de la mezquita, en Granada Catedral y Alambra se miraban frente a frente. La ciudad lorquiana continuaba siendo un paraíso que conservaba la belleza de lo salvaje y desconocido. Una alucinación soñadora que, no obstante, se enfrentaba al sistemático ataque de una "legión de ratas", los turistas anglosajones empeñados en llevarse algo de su magia. El repudio de ese turismo de masas que desvirtuaba paisajes, ambientes y formas de vida, se percibe en cuantos viajeros latinoamericanos visitaron Andalucía. Como defensa, apuntaba alguno, los granadinos habían creado una Granada para consumo turístico, La Zambra, en tanto que la ciudad íntima permanecía vedada al forastero. La esencia de la ciudad, pues, no la componían toreros, cupletistas, gitanas con vuelo de faralaes, garrochistas, mendigos patéticos y enanos trágicos que los turistas se empeñaban en fotografiar, sino:

...la tragedia quimérica de abecenrrajes degollados, Marianas Pineda, obreros asesinados a las puertas de sus casas del Albaicín en 1936...la quimera de Federico García Lorca, asesinado al amanecer en el barranco de Viznar por la pasión política sin freno y las viscosas envidias literarias amparadas en la vesania alcohólica de aquel jerarca militar de Sevilla que aspiraba a dormir sobre un lecho de senos cortados y cadáveres infantiles, ¡Dios le haya concedido la gracia de incumplir su anhelo para que el fuego del infierno le resulte mas leve! ${ }^{55}$.

Córdoba, denominada paradójicamente "capital de la España andaluza", aparecía dibujada como una ciudad hedonista y sapiente, que dormía de día y abría sus ojos de noche. Imágenes cristianas, judías y árabes se fundían en una urbe a la que la revista Siempre, que le dedicó un suplemento fotográfico, consideraba la cumbre del amor y del placer.

Si Sevilla constituía el reencuentro con su origen criollo, Cádiz lo era con los padres de la independencia. El parecido con Buenos Aires resultaba tan evidente a Ricardo Rojas como lo era la similitud entre Sevilla y Lima para Ricardo Palma o con Puebla para los mexicanos. La fisonomía urbana de la ciudad, incluso el nombre de las calles, evocaba a América. Cádiz era

...el gader de los fenicios, fundada mil años antes de nuestra era. Fue ya entonces un establecimiento mercantil y una fortaleza amurallada, como ha seguido siéndolo hasta hoy. Han pasado por ella, disputándose su posesión o explotando su comercio, cartagineses y romanos, griegos y judíos, moros y cristianos...No son sin embargo esos los títulos que mas enorgullecen a los gaditanos...Lo que engríe a los gaditanos es el llamar a Cádiz la tacita de plata, por la belleza de la ciudad blanca y redonda en medio de la mar verde; y saber que allí nació el liberalismo con la Constitución de 1812 y con la revolución de Riego en 1820, ambas frustradas por las traiciones de Fernando VII, pero ambas influyentes en el destino

55 Raul Andrade, “Quimeras de Granada”, El Diario de Yucatán, 18-3-1979, p. 1, 4-D. 
de la nación, desde el siglo pasado hasta nuestros días... aunque nuestras historias digan que vienen de la revolución francesa el constitucionalismo y el liberalismo sudamericano vienen de Cádiz"56.

Tan honda huella dejó el viaje por esas tierras en Palma que terminó por asegurar que "la constante injerencia de Europa en España ha sido la causa de estas fatalidades", en referencia a un genio ibérico cuyo espíritu reposaba en el Cádiz de las Cortes, truncado por los intereses de dinastías extranjeras que no habían dejado a España ser ella misma ${ }^{57}$.

Sobre los tipos que habitaban las calles andaluzas la imagen más extendida afirmaba que a pesar de la pereza, la indolencia, la inmoralidad, la suciedad, que llamaban la atención de muchos viajeros, eran gente alegre, auténtica en su primitivismo, capaz de soportar la pobreza con estoicismo oriental. Los textos de Borrow primero y de Irving Brown en las primeras décadas del siglo XX dieron forma en EEUU a una escuela anglosajona de filogitanismo, vigente durante toda la primera mitad del siglo $\mathrm{XX}^{58}$. En ella se admiraba al gitano andaluz por su primitivismo, su libertad, su misterio, su fantasía, su rechazo de la vida cotidiana gris y homogeneizada que imponía la civilización. Muchos fueron los que, como Brown, llegaron a Andalucía en busca del gitano auténtico. No lo encontraron en Triana, sino en Coria o en Guadix.

Las encuestas sociológicas llevadas a cabo en América por el Instituto Elcano revelan la actualidad de muchos de esos estereotipos. Los españoles, sobre todo andaluces, continúan siendo divertidos, auténticos, pasionales. Les distingue un envidiable gusto por la vida, pero cuando se pregunta por aspectos como innovación, calidad de productos, estilo, modernización, los resultados son desoladores. En EEUU porque ni siquiera tienen una imagen económica de España. La situación resulta menos negativa en América Latina. No obstante, los españoles siguen siendo allí arrogantes, soberbios, poco amistosos y hostiles. Ciertamente esa visión resulta más evidente en unos países que en otros, pero demuestra hasta que punto los viejos estereotipos continúan circulando.

$$
* * *
$$

El verdadero problema es que esos estereotipos de los andaluces, que han terminado identificando a los españoles, continúan siendo utilizados en muchas campañas publicitarias; sin duda porque su rentabilidad sigue estando asegurada ${ }^{59}$. Pero es que tampoco estoy segura de que exista mucha diferencia con la imagen que la Junta de

56 Ricardo Rojas, op. cit., p. 147.

57 Ib. 151.

58 Uno de los textos más significativos de esta escuela es La senda gitana de Irving Brown, reeditado en Sevilla por la editorial Renacimiento, en 2006.

59 En los años ochenta la campaña Bravo España puesta en marcha por la agencia estatal Tourespanña para promocionar el turismo fue retirada tras constatar su fracaso. En ella se vendía una imagen de la Península que pretendía huir del sol y la playa para atraer a un turismo de más alta calidad. El fracaso de aquella contrasta con el éxito de la campaña "Todo bajo el Sol" que explotaba todos los tópicos de la imagen de España romántica, de la Andalucía romántica para ser más exactos. 
Andalucía divulga en sus campañas institucionales; o, lo que es peor, con la autoimagen que la televisión autonómica se encarga de difundir. El uso del mito puede estar justificado. Puede que, como defiende Enrique Baltanás, no haya problema en mantener esa imagen romántica y castiza, si es útil para mantener el sector turístico ${ }^{60}$. En todo caso, lo importante es saber qué imagen queremos proyectar, en realidad qué pretendemos ser. Si es la imagen que hasta ahora hemos proyectado, no hay más que decir.

60 Enrique Baltanás, Las columnas de Hércules. Realidad o invención de Andalucía, Sevilla: Signatura, 1999. 